\title{
The Reception of Classical Authors in Taiwan
}

\section{Christopher Joby ${ }^{1}[$}

Published online: 31 July 2020

(c) The Author(s) 2020

\section{Introduction}

Harold Marcuse describes reception history as 'the history of the meanings that have been imputed to historical events. It traces the different ways in which participants, observers, historians and other retrospective interpreters have attempted to make sense of events both as they unfolded and over time since then, to make those events meaningful for the present in which they lived and live. ${ }^{1}$ In recent years, there has been increased academic interest in the reception of the languages and cultures of classical antiquity in East Asia. For example, in 2019 an edited volume on the reception of Greek and Roman antiquity in East Asia was published, which includes essays on the reception of antiquity in Ming and Qing China and Tokugawa Japan in the sixteenth and seventeenth centuries. ${ }^{2}$ As for another area of East Asia, Taiwan, one chapter in the book examines classical architectural elements in buildings on the island, but this mainly concerns the period of Japanese occupation (1895-1945). ${ }^{3}$ There is, however, little on the reception of the classical tradition in Taiwan prior to this time, including the age of European expansion of the sixteenth and seventeenth centuries. In the present article I attempt to address this situation by exploring how meaning was imputed to texts from classical antiquity in seventeenth-century

\footnotetext{
${ }^{1}$ http://marcuse.faculty.history.ucsb.edu/receptionhist.htm. Accessed 20 May 2020.

${ }^{2}$ Receptions of Greek and Roman Antiquity in East Asia, ed. A. Renger and Xin Fan, Leiden, 2019. For Japan, see, e.g., I. Taida, 'History and Reception of Greek and Latin Studies in Japan', ibid., pp. 73-90. For China, see N. Golvers, 'Reading Classical Latin Authors in the Jesuit Mission to China', ibid., pp. 50-72, and A. Müller-Lee, 'The Jesuit Mission to China and the Reception of Ancient Greek and Roman Culture in China and Korea', ibid., pp. 19-49. See also I. Taida 'The Earliest History of European Language Education in Japan: Focusing on Latin Education by Jesuit Missionaries', Classical Receptions Journal, 9, 2017, pp. 566-86, and N. Golvers, Ferdinand Verbiest and Jesuit Science in 17th Century China: An Annotated Edition and Translation of the Constantinople Manuscript, Leuven, 2009.

${ }^{3}$ Chia-Lin Hsiu, 'Politics, Culture, and Classical Architectural Elements in Taiwan', in Receptions of Greek and Roman Antiquity (n. 2 above), pp. 342-62.
}

The research for this article was conducted with the financial support of the MoFA, Taiwan, and the institutional support of the National Taiwan Normal University, Taipei.

Christopher Joby

christopherjoby@gmail.com

1 Department of Dutch and South African Studies, Adam Mickiewicz University, Poznan, Poland 
Taiwan, where Dutch and Spanish merchants and missionaries were active and had regular contact with indigenous Formosan peoples. In some sense this complements a recent article of mine on the reception of ancient Latin and Greek authors in Tokugawa Japan. ${ }^{4}$ One important difference, however, is that whereas Japan was already a highly literate society when Europeans first arrived there in the mid-sixteenth century, the indigenous Formosan people were not literate. Furthermore, we have no texts written by them during the period of contact with Europeans, and so we must view their reception of classical authors through the prism of Dutch and Spanish records, which raises methodological questions.

My study begins with a brief account of the Dutch and Spanish presence on the island and their contact with indigenous Formosans to give the reader the necessary historical context. These Europeans were in Taiwan for two principal reasons: to trade and to convert the indigenous Formosans either to Reformed Protestant or to Roman Catholic Christianity. Given that the latter activity necessarily involved questions of faith and that the reception of explicitly Christian texts from antiquity differed in kind as well as degree from that of secular texts, I intend to explore this phenomenon in future publications. My focus here is instead on the reception in Taiwan of texts which are not explicitly Christian. These include texts by pagan authors such as Cicero and Ovid as well as legal texts compiled by order of the Emperor Justinian (482-565 AD).

After the brief historical account, I analyse which books by classical authors were brought to Taiwan by the Dutch and Spanish. I then focus on the reception of these authors by Dutchmen in Taiwan. From the evidence that we have, the one who most frequently cited classical authors was Pieter Nuyts (1598-1655), who was the Dutch East India Company (Vereenigde Oostindische Compagnie, or VOC) Governor of Taiwan between 1627 and 1629. I therefore examine how he subjected his classical sources to various rhetorical transformations to make these works, written in the past, "present'. ${ }^{5}$ As to the question of whether texts by classical authors reached the indigenous Formosans and, if so, how they responded to them, here we face the methodological problem that we have no surviving documents written by the Formosans from this period. Therefore, we must rely on European sources to try to build up a picture of contact with and reception of texts by classical authors by indigenous Formosans. Probably the most promising avenue of investigation in this regard is a Dutch edition of a primer by Johannes Amos Comenius which was used in a seminary established for the Siraya people in 1659. This seminary, however, only functioned for a few years, since in 1662 the Dutch were expelled from Taiwan by the Chinese merchant-cum-warlord Zheng Chenggong (also known as Koxinga 1624-62). ${ }^{6}$ This first attempt at studying the reception of classical authors in Taiwan aims to increase our understanding of how their works were received in East Asia, as well as to problematize questions of reception in an oral culture.

\footnotetext{
${ }^{4}$ C. Joby, 'The Reception of Ancient Latin and Greek Authors in Japan (1550-c. 1850)', International Journal of the Classical Tradition, 26, 2019, pp. 270-94.

5 D. Kennedy 'Afterword: The Uses of "Reception"”, in Classics and the Uses of Reception, ed. C. Martindale and Richard F. Thomas, Oxford, 2006, pp. 288-93 (289).

${ }^{6}$ De Dagregisters van het Kasteel Zeelandia, Taiwan, 1629-1662, ed. L. Blussé et al., 4 vols, The Hague, 1986-2000, III, p. 75.
} 


\section{The Dutch and Spanish in Taiwan: An Overview}

In the late sixteenth century, Europeans had very occasional contact with Taiwan. It was, however, not until 1624 that they developed more permanent connections with the island, in the shape of the VOC, which first established a base there. ${ }^{7}$ At this time, Taiwan was inhabited by various groups of indigenous Austronesian people (referred to here as Formosans) and about 10,000 Chinese from Fujian (Fukien) and Guangdong provinces, who were for the most part traders, fishermen, pirates and smugglers. Initially, the Dutch colonized the southwestern part of the island, using as their base what became Fort Zeelandia. ${ }^{8}$ This base on Tayouan Bay functioned as a stopover for ships sailing to and from the VOC trading posts in Japan and as an entrepôt for trading with Chinese merchants. ${ }^{9}$

According to one estimate there were no more than 2,800 VOC employees on Taiwan, of whom 2,200 were soldiers. ${ }^{10}$ The head of the trading post was the Governor, appointed by the Governor-General of the VOC at Batavia. Several of the early Governors of Taiwan were graduates of Leiden University, established in 1575. Martinus Sonck, the first VOC Governor in Taiwan (1624-25) was educated at Leiden. ${ }^{11}$ The third Governor, Pieter Nuyts, was also a Leiden graduate. ${ }^{12}$ He took a library of classical works with him, possibly in a large chest, and often sprinkled his letters with quotations from ancient authors, which form an important part of our story.

To the southeast of Taiwan lie the Philippines. The Spanish had occupied parts of these islands since the middle of the sixteenth century. The Dutch Republic was at this time engaged in the Eighty Years' War with Spain, and so the Spanish in the Philippines feared that the Dutch might launch an attack from their new base in Taiwan. Therefore, in 1626 the Spanish sent a small armada to occupy the northern part of Taiwan. It arrived in Quelang on 10 May 1626, and conquest was finalized six days later. The rationale for establishing a base in Taiwan was not merely military, but was also related to the Catholic mission, as it was argued that Taiwan could act

\footnotetext{
7 A. Clulow, 'Commemorating Failure: The Four Hundredth Anniversary of England's Trading Outpost in Japan', Monumenta Nipponica, 68, 2013, pp. 207-31 (222); A. Heylen, 'Dutch Language Policy and Early Formosan Literacy (1624-1662')', in Missionary Approaches and Linguistics in Mainland China and Taiwan, ed. Ku Wei-ying, Leuven, 2001, pp. 199-252 (202).

8 Heylen, 'Dutch Language Policy' (n. 7 above), p. 239, n. 186.

9 R. Kagan, 'The Dutch in Taiwan', in A Historical Companion to Postcolonial Literatures: Continental Europe and Its Empires, ed. L. Jensen et al., Edinburgh, 2008, pp. 354-6 (355).

10 Ibid., p. 355, and I-Shou Wang, 'Cultural Contact and the Migration of Taiwan's Aborigines: A Historical Perspective', in China's Island Frontier: Studies in the Historical Geography of Taiwan, ed. R. G. Knapp, Honolulu, 1980, pp. 31-54 (36).

11 J. E. Borao, The Spanish Experience in Taiwan 1626-1642: The Baroque Ending of a Renaissance Endeavor, Hong Kong, 2009, p. 191. Sonck matriculated to study philosophy on 17 October 1612. He is listed as Martinus Souckius in W. du Rieu, Album studiosorum Academiae Lugduno Batavae MDLXXVMDCCCLXXV: accedunt nomina curatorum et professorum per eadem secula, The Hague, 1875, col. 107. This is probably a typographical error, as one would expect Sonckius.

$12 \mathrm{He}$ is listed as Petrus Nuytius. He matriculated to study philosophy on 14 December 1613: Du Rieu, Album studiosorum (n. 11 above), col. 114.
} 
as a transit point for missionaries heading to mainland China. ${ }^{13}$ In the late 1620 s and early 1630s, some 40 Dominicans (including two Japanese) arrived in Taiwan, while eight Franciscans arrived in 1633 with the aim of moving on to China. ${ }^{14}$ We have few details about their education. We do, however, know that two Dominicans in Taiwan had taught at the University of Santo Tomás in Manila and that one of them planned to establish a seminary in Taiwan. ${ }^{15}$ Churches were built alongside military forts as the Spanish set about establishing their colony in northern Taiwan; but this colonial project was not a success, and in 1642 the Dutch, who were still at war with Spain, drove the Spanish out of Taiwan. ${ }^{16}$

By 1650 , the Dutch had control over 315 villages with a population of $68,567 .^{17}$ Dutch Calvinist missionaries had been active in Taiwan since the late 1620s. The first ordained minister in Taiwan was the Leiden graduate, Georgius Candidius (1597-1647). ${ }^{18}$ He was in Taiwan from 1627 to 1631 and again from 1633 to $1637 .{ }^{19}$ He built a bamboo hut in Sinkan, one of the villages of the Siraya people who lived on the plains close to Fort Zeelandia in the southwest of the island. ${ }^{20}$ There, he carried out the role of field missionary and wrote a brief ethnography describing the customs, manners and religion of the inhabitants. The Siraya lived in seven other villages near Sinkan, where similar customs were practised and varieties of the same language were spoken. ${ }^{21}$ The language belongs to the Formosan language group within the broader Austronesian language family. Candidius's successor, Robertus Junius (1606-1655), who arrived in Taiwan in 1629 and left in 1643, was also a graduate of Leiden University, which had been established in part to provide an education for future ministers of the Dutch Reformed church. ${ }^{22}$ Junius learnt Siraya and compiled a catechism in the language. ${ }^{23}$

\footnotetext{
${ }^{13}$ Borao, The Spanish Experience (n. 11 above), pp. 46, 108.

${ }^{14}$ Ibid., pp. 175-6; 244-7. For a comprehensive list of the Dominicans and Franciscans who went to Taiwan, see J. E. Borao, Spaniards in Taiwan, 2 vols, Taipei, 2002, I, pp. xxxiv-xxxv.

${ }^{15}$ Borao, The Spanish Experience (n. 11 above), p. 190.

${ }^{16}$ Heylen, 'Dutch Language Policy' (n. 7 above), pp. 203-4. For a detailed account of the Spanish period in Taiwan, see Borao, The Spanish Experience (n. 11 above).

${ }^{17}$ J. E. Wills, 'The Seventeenth-Century Transformation: Taiwan under the Dutch and the Cheng Regime', in Taiwan: A New History, ed. M. A. Rubinstein, London, 1999, pp. 84-106 (91); Wang, 'Cultural Contact' (n. 10 above), p. 38.

${ }^{18}$ Du Rieu, Album studiosorum (n. 11 above), col. 157.

${ }^{19}$ Heylen, 'Dutch Language Policy' (n. 7 above), pp. 204-5.

${ }^{20}$ Ibid., p. 206; A. Adelaar, Siraya: Retrieving the Phonology, Grammar and Lexicon of a Dormant Formosan Language, Berlin, 2011, pp. 12-13.

${ }^{21}$ The eight villages are: Sinkan (present Xinshi), Mattau (present Madou), Soulang (present Jiali), Bakloan (present Anding), Taffakan or Tavocan (present Xinhua), Tifulukan, Teopan and Tefurang or Tevorang (present Yujin). These names are often recorded in different orthographical variants. Heylen 'Dutch Language Policy' (n. 7 above), p. 205, n. 29. The Siraya language probably became extinct at some point in the nineteenth century as a result of extensive contact with the Chinese Hokkien language and culture; Adelaar, Siraya (n. 20 above), p. 15.

${ }^{22} \mathrm{He}$ matriculated to study theology on 3 March 1626 (listed as Robertus de Jonghe): Du Rieu, Album studiosorum (n. 11 above), col. 191.

${ }^{23}$ Heylen, 'Dutch Language Policy' (n. 7 above), pp. 209-12.
} 
As the missionary work gathered pace, many churches and schools were built. In the early 1640s the VOC began to encourage the teaching of Dutch to indigenous people in the areas of South and East Asia that it controlled. ${ }^{24}$ It was not until February 1648 , however, that Dutch was officially introduced in schools in Taiwan. ${ }^{25}$ From this time onwards, there was an increased use of Dutch alongside the native tongues, giving rise to a certain level of bilingualism. The school day was divided, so that instruction was given in the 'Formosan language', that is, Siraya, in the morning and Dutch in the afternoon. ${ }^{26}$ In November 1648 the church consistory at Tayouan reported that the experiment to teach Dutch to local people was having great success. ${ }^{27}$ In 1659 , a seminary was established to educate thirty indigenous seminarians. ${ }^{28}$ A Dutch edition of a primer by Comenius was used for instruction. This had been published in 1658 in Amsterdam by Gabriel de Roy as Portael der saecken en spraecken: Vestibulum rerum et linguarum ('Entryway of Things and Languages').

All this came to an end in 1662, however, when, after a long siege, Koxinga defeated the Dutch. During the Dutch period in Taiwan, the number of Chinese had increased dramatically as a result of political instability on the mainland towards the end of the Ming dynasty and the Dutch need for migrant labour to work as taxfarmers. ${ }^{29}$ By 1661 there were as many as 50,000 Chinese on Taiwan. ${ }^{30}$ There is little evidence, though, that the Dutch tried to educate them as they did the indigenous people in Taiwan, and it is most unlikely that the Chinese came into contact with classical authors via the Dutch.

\section{Editions of Works by Classical authors in Taiwan}

Evidence for the reception of classical authors in Taiwan comes above all in two forms. First, private and communal book catalogues and inventories include works by some ancient authors. Second, Dutch authors refer to works by these authors, typically in the form of quotations.

\footnotetext{
${ }^{24}$ K. Groeneboer, Gateway to the West: The Dutch Language in Colonial Indonesia: A History of Language Policy, Amsterdam, 1998, p. 50.

25 Heylen, 'Dutch Language Policy' (n. 7 above), p. 224. See also Archief voor de Geschiedenis der Oude Hollandsche Zending, 6 vols, Utrecht, 1884-91, II, p. 188.

${ }^{26}$ Heylen, 'Dutch Language Policy' (n. 7 above), p. 232. W. Campbell, Formosa under the Dutch, Described from Contemporary Records, London, 1903 [reprint Taipei, 1992], pp. 242, 307-8.

27 Campbell, Formosa under the Dutch (n. 26 above), pp. 232, 242.

28 S. Fujii, 'The Formation of Taiwanese Identity and the Cultural Policy of Various Outside Regimes', in Taiwan under Japanese Colonial Rule 1895-1945: History, Culture, Memory, ed. P.-H. Liao and D. D.-W. Wang, New York, 2006, pp. 62-77 (64). See also H.-H. Chiu, The Colonial 'Civilizing Process' in Dutch Formosa: 1624-1662, Leiden, 2008, p. 202, for the establishment of the seminary.

29 Heylen, 'Dutch Language Policy' (n. 7 above), p. 235-8.

30 Fujii, 'The Formation of Taiwanese Identity' (n. 28 above), p. 64. Kagan, 'The Dutch in Taiwan' (n. 9 above), p. 354, gives a figure of between 40,000 and 50,000.
} 
After defeating the Spanish in 1642, the Dutch made a catalogue of the books they found in the fort of Quelang. ${ }^{31}$ There were 118 books in the catalogue. Almost all of them, however, concern the Christian tradition, many of them written by CounterReformation theologians like Luis de Granada. ${ }^{32}$ These books were shipped by the Dutch to Tayouan. ${ }^{33}$ In 1643, the Dutch church consistory at Tayouan established a library. ${ }^{34}$ The most extensive list we have of the books in this library is undated. ${ }^{35}$ Most of these books are, as one might expect, works on the Bible and the Christian tradition. There are 76 entries, although two of these - '56, Books on medicine' and '76, A small collection of little books' - indicate that the total number of books was higher. Again, there are very few works by pagan authors from antiquity in this list. One exception is Cicero's Opera (75). Other works in the collection do, however, contain material from classical authors. Among these are the thirteenth-century astronomical textbook De sphaera (13) by Johannes de Sacroboscus (c. 1195-c. 1256), which relies heavily on Ptolemy's Almagest, and Johann Heinrich Alsted's (1588-1638) Cursus philosophici encyclopaedia (libris XXVII) (16), first published in 1620, which makes extensive use of Aristotle and other ancient philosophers.

Clearly, there were very few non-Christian books in these communal libraries. So, we must turn to private collections to see whether they included a larger number of such books. Here, again, in the first instance, we face the problem of identifying suitable sources. For example, in 1662, the Dutch missionary Joannes Kruyf managed to escape with his family from Taiwan; and in a letter that he wrote to a colleague in Ceylon, he complained that he had lost 'three parts' of his library, but unfortunately giving no further details. ${ }^{36}$ More promising is the substantial collection of classical authors in Taiwan belonging to the third Governor, Pieter Nuyts. As has already been hinted at, not only did Nuyts possess such a collection, but he also quoted from the works of several classical authors, using a range of rhetorical transformations. So, let us now turn to Nuyts. I shall first provide a brief account of his life, then indicate the works by classical authors in his possession and, finally, analyse the various ways in which he inserted quotations from these authors into his own writings.

\footnotetext{
${ }^{31}$ MS The Hague, Nationaal Archief, VOC (1.04.02) 1146, fol. $744^{\mathrm{r}-\mathrm{v}}$. The Dutch catalogue is a poor transliteration of the original titles. Borao, Spaniards in Taiwan (n. 14 above), II, pp. 400-3, has tried to reconstruct it using the UST (Manila) Rare Books Collection.

${ }^{32}$ Borao, Spaniards in Taiwan (n. 14 above), II, pp. 400-3; Borao, The Spanish Experience (n. 11 above). p. 191.

${ }^{33}$ Borao, Spaniards in Taiwan (n. 14 above), II, p. 400.

${ }^{34}$ De Dagregisters (n. 6 above), II, p. 196: 'Alsmede dat de Compagnie 74 ende de diaconye 50 rl. van achten tot het stabileeren van een bibliateeck contribueeren.'

${ }^{35}$ Archief voor de Geschiedenis (n. 25 above), III, pp. 233-5; English translation: Campbell, Formosa under the Dutch (n. 26 above), pp. 328-30.

${ }^{36}$ Campbell, Formosa under the Dutch (n. 26 above), p. 328.
} 


\section{Pieter Nuyts}

Nuyts was born in Middelburg in Zeeland in 1598. He had matriculated at Leiden University aged fifteen and graduated with a doctorate in philosophy in $1620 .{ }^{37}$ In 1626, he joined the VOC to make money and gain status. In 1627, he arrived in Batavia (now Jakarta on Java), the centre of VOC operations in East Asia. The VOC's leaders were, in the words of Adam Clulow, keen to replace 'the rough adventurers that had initially flocked to Asia', with 'a new generation of educated men better suited to employment in an increasingly prosperous organization'. ${ }^{38}$ Nuyts was one of this new generation. Almost immediately, he was appointed Governor of Taiwan. First, however, he was required to visit the shogun's court in Edo (now Tokyo), Japan, to try to negotiate better terms for the VOC. Unfortunately, this was unsuccessful, and so Nuyts left for Fort Zeelandia to take up his new position. In early 1628 , the (unfounded) fear arose among VOC officials that the Japanese were planning to attack the Dutch in Taiwan to eject them from the island. This was communicated to Nuyts but led to a 'Comedy' or perhaps 'Tragedy of Errors'. In April 1628, two Japanese junks commanded by Hamada Yahyoe arrived in Tayouan Bay. Fearing that this was the start of an invasion, Nuyts ordered the vessels to be searched and stripped of their weapons. Hamada was detained, but after two months he grew impatient and, using a ruse, managed to take Nuyts hostage. Having negotiated compensation, Hamada returned to Japan; however, he brought these events to the attention of the shogun, and the Japanese suspended trading with the VOC. ${ }^{39}$ Meanwhile, Nuyts tried to develop the VOC's trade with China. He managed to seal a three-year contract with the Chinese merchant, Iquan; but Iquan could not deliver on it as his former subordinate Quitsicq turned against him, and, as Nuyts would later report, he was also foiled by unfavourable winds.

By April 1629, the VOC representatives in Batavia had lost their patience with Nuyts, and he was replaced as Governor by Hans Putmans. In August 1629, Nuyts composed an extended apologia, of which more below; but, despite his best efforts, in 1630 he was required to face the music for his actions and went to Batavia. While he was there, it was decided that the only way to start trade with Japan again would be to offer a sacrificial lamb, in the form of Nuyts. He was thus dispatched to Japan, where he spent four years under house arrest. Nevertheless, he used his time to write two books: Lof des Elephants ('Praise of the Elephant'), and Beschrijvinge vande Riviere Nylus in Aegypten ('Description of the River Nile in Egypt'). ${ }^{40}$

\footnotetext{
37 A. Clulow, The Company and the Shogun: The Dutch Encounter with Tokugawa Japan, New York, 2014, p. 72; L. Blussé, 'Bull in a China Shop: Pieter Nuyts in China and Japan (1627-1636)', in Around and about Formosa. Essays in Honor of Professor Ts'ao Yung-ho, ed. L. Blussé, Taipei, 2003, pp. 95-110 (102).

38 Clulow, The Company and the Shogun (n. 37 above), p. 72.

39 For a detailed account of this episode, see ibid., pp. 226-54.

40 See Beschrijvinge vande Riviere Nylus in Aegypten: MS The Hague, Koninklijke Bibliotheek, 132 G 21. Justus Lipsius's 't Lof van de Olyphant is likely to have been the inspiration for Nuyts's work; see Blussé, 'Bull in a China Shop' (n. 37 above), p. 110, n. 19.
} 
Both books draw heavily on classical authors. I shall not describe them in detail, since Nuyts wrote these works in Japan and not in Taiwan; however, in the front matter of Lof des Elephants is a list of the authors to whom he refers. It is reasonable to assume that he had most of these with him in Taiwan. ${ }^{41}$ Among the pagan authors of antiquity whom Nuyts lists are Aelian, Appian of Alexandria, Aristotle, Aulus Gellius, Julius Cæsar, Cicero (De officiis, De natura deorum, De senectute, De amicitia, Quaestiones Tusculanae), the fifth-century BCE Greek historian and physician Ctesias, Dio Cassius, Diodorus Siculus (Bibliotheca Historica), Diogenes Laertius, Dionysius of Halicarnassus, the Roman civil engineer and author Frontinus, Herodotus, Homer, Livy, Lucian, Lucretius, Macrobius, Pliny the Elder, Plutarch, Quintilian, Sallust, Seneca (De ira, Epistulae morales, De beneficiis, De clementia, De consolatione ad Helviam), the fifth-century Greek compiler Stobaeus, Strabo, Suetonius, Tacitus (Annales and Historiae), Valerius Maximus and Virgil. To these we can add the Corpus Iuris Civilis compiled in the sixth century on the order of Emperor Justinian. Furthermore, there are several Renaissance writers who refer to classical authors in Nuyts's list. These include the Dutch humanist Erasmus (c. 1466-1536) (Apophthegmata and Colloquia) and the Flemish humanist Justus Lipsius (1547-1606) (De constantia and Exemplorum \& monitorum politicorum libri duo). Lipsius's De constantia was one of Nuyts's consolations while incarcerated in Japan. ${ }^{42}$

I next want to analyse examples of how Nuyts de-contextualized and re-contextualized phrases from classical and late ancient authors to give meaning to events in Taiwan in which he was involved. We see this most clearly in letters that he wrote from Tayouan to Batavia. On 4 February 1629, Nuyts wrote to the VOC GovernorGeneral in Batavia, Jan Pietersz. Coen (1587-1629), urging him to speed up work on fortifications at Fort Zeelandia to minimize the threat from ships of other nations such as the Chinese and Portuguese. He invoked antiquity to make his case, reminding Coen that while Rome was busy deliberating the Carthaginians took Saguntum in Spain (219 BCE). ${ }^{43} \mathrm{He}$ also quotes comments that Cicero made in a similar situation in a letter to the Roman senator, Lucius Monatius Plancus (Epistulae ad familiares, X.xvi). Here, Cicero exhorts Plancus not to refer matters to the Roman Senate but rather 'Be the Senate for yourself' ('Ipse tibi sis senatus'). Nuyts concludes the long quotation with the final sentence of Cicero's letter: 'Illud tibi promitto quidquid a te facturum, id senatum non modo ut fideliter sed etiam ut sapienter factum comprobatarum' ('This I promise you, that whatever your achievement, the Senate will heartily applaud it as a proof, not only of your loyalty, but also of your wisdom'). ${ }^{44}$

\footnotetext{
41 Nuyts did acquire some books from the physician Dr Bontius in Batavia after leaving Taiwan, although we have no further details; see Blussé, 'Bull in a China Shop' (n. 37 above), p. 105, who notes that Nuyts had a 'travelling reference library' of some 70 titles, which is about the same number as the list of authors and works in the front matter of Lof des Elephants.

42 Blussé, 'Bull in a China Shop' (n. 37 above), p. 110.

43 Dutch: Want terwijle men tot Roomen met veel delibererens besich was, wert Saguntium van de Cartageniers ingenomen.

44 De missiven van de VOC-governeur in Taiwan aan de Gouverneur-Generaal te Batavia, Tainan, 2007-, II: 1629-1631, p. 7. Nuyts quotes from 'hoc animo esse debes' to 'sed etiam sapienter factum comprobatarum [recte: comprobaturum]'.
} 
He is thus imploring his addressee, Coen, to rely on his own judgement. Nuyts added that another VOC employee, Mr Courten, was not making progress in this matter with the governing body of the VOC, De Heren XVII ('the Seventeen Lords'), in far-away Amsterdam, and so Coen must simply act on his own. Otherwise, he fears, the colony of Taiwan may be lost, something which would harm the VOC. So here, Nuyts is drawing a parallel between events in antiquity and those in his own time to make the past present and to give meaning to the circumstances in which he finds himself. Importantly, he quotes the final sentence of Cicero's letter, perhaps to reassure Coen, but also to play to his correspondent's ego, by telling him he will be applauded by the Senate, that is, De Heren XVII. Finally, of course, Nuyts is casting Fort Zeelandia as Saguntum and perhaps Amsterdam as the new Rome, a not infrequent trope in the Dutch Republic. Rome had faced opposition from Carthage in its drive to expand, and so, now, the VOC was facing opposition from various forces, above all, Chinese warlords; and Nuyts hopes that, just as Rome eventually defeated Carthage, the VOC will eventually overcome its own adversaries.

In the following month, March 1629, in the wake of his clash with Hamada Yahyoe and several other unsuccessful ventures, Nuyts was relieved of his duties as Governor. He spent the next fourteen months or so at Zeelandia on Taiwan before eventually being forced to go to Batavia to be questioned by his superiors. As mentioned above, he composed a lengthy letter, which served as an apologia for his actions; dated 14 August 1629 and addressed to the Governor-General in Batavia, it is replete with quotations from Roman authors, which Nuyts reworked for his own purposes. $^{45}$

At one point in the letter, Nuyts records that he had held Hamada Yahyoe captive, depriving him and some of his crew of food and water, as this was the only way to stop Hamada's protests and to show him that Nuyts was in control of the situation. ${ }^{46}$ He observes that Hamada had not, however, been starved to death, but given food and water again after five or six days. Here, Nutys quotes from the 'Life of Cato the Elder' by Plutarch, who records that Cato once wished to dissuade the Roman people from insisting 'unseasonably' on the distribution of corn. Recognizing, nevertheless, that the people were hungry, Cato began his speech by saying that he would like to reason with their bellies but that it was difficult 'to speak to a stomach, as it does not have ears' (viii.1). Nuyts writes: 'Perdifficile est (seght Cato) ad carentem auribus ventrem verba facere, venter quippe cibi avidus praecepta non audit!' ('It is very difficult, Cato says, to speak to a stomach lacking ears, for a stomach that longs for food does not listen to precepts'). ${ }^{47}$ This would appear to be based on an extant Latin translation of Plutarch's sentence, such as the one in a Florilegium published at the time: 'Cato ... ait, Perdifficile esse ad carentem auribus ventrem verba facere,

\footnotetext{
45 Blussé, 'Bull in a China Shop' (n. 37 above), p. 104.

46 Clulow, The Company and the Shogun (n. 37 above), p. 227; François Valentijn, Oud en Nieuw OostIndien, Dordrecht and Amsterdam, 5 vols, 1724-1726, IV, p. 53 (Book 4, Chapter 4).

47 De missiven van de VOC-governeur (n. 44 above), p. 89.
} 
venter quippe cibi avidus praecepta non audit! ${ }^{48}$ This version includes an amplificatio that fits the situation in which Nuyts found himself, for he realized that he would have to give Hamada food and water in order to gain his attention and to get him to listen to his praecepta. ${ }^{49}$ So, Nuyts was appealing to an ancient authority in order to justify to his superiors why he had given food and water to his captive after having previously refused to do so.

In the same letter-cum-apologia, Nuyts inserts quotations from the Digest, part of Justinian's Corpus Iuris Civilis, first issued on 16 December $533 .{ }^{50}$ One of these is from the Digestum Novum XXXXIII, De obligationibus et actionibus ('On Obligations and Actions'), 7.38. ${ }^{51} \mathrm{He}$ recalls a decision to give a pass to the Chinese pirate (rover) Quitsicq, who, as noted above, had turned against his master Iquan. Nuyts concludes the passage by quoting from the Digest: 'Non figura litterarum, sed oratione, quam exprimunt litterae, obligamur', adding in Dutch, 'seght den text' ('says the text'). The Latin means: 'We are bound not by the form of the written words (i.e., letters), but by the meaning that they express. ${ }^{52}$ He then asks rhetorically whether, on the one hand, he should give someone, that is, Quitsicq, a trading pass and then, on the other hand, attack him ('sal ick met mynen pas een ider sulcx gelasten, ende selffs aen d'ander syde ... hem aengrypen?'). Clearly, for Nuyts the answer is 'no', for, despite Quitsicq's actions, he did not order an attack on him. Here, although there is no rhetorical transformation as such, Nuyts does de-contextualize and re-contextualize the passage from the Digestum Novum to give meaning to his own circumstances. In addition, he probably quotes from this authoritative legal text in Latin here and elsewhere because, recognizing that his actions have not been successful, he wants to present himself as a professional jurist, hoping to convince his readers that there was legal justification for his actions, so that they will judge him less harshly than otherwise might have been the case. As well as illustrating his familiarity with this late classical text, his re-contextualization thus has a very practical purpose.

Another ancient author whom Nuyts quotes in his apologia of 14 August 1629 is Seneca the Younger. In a passage recounting his attempts to open trade with China, he points out that he had made some progress, but that adverse winds had prevented him and his ships from making as much progress as he would have liked. Moreover, he writes that he was forced to end the mission, as the Governor-General had commanded him to complete it by the beginning of October. To underline his point, he

\footnotetext{
48 See, e.g., Domenico Nani Mirabelli et al., Florilegii magni, seu polyantheae floribus novissimis sparsae, libri XX, Frankfurt, 1621, p. 1067. Although the list of books given above does not include this or other Florilegia, it is likely that there was one in the portable library that Nuyts took with him.

${ }^{49}$ H. Lausberg, Handbook of Literary Rhetoric: A Foundation for Literary Study, transl. M. T. Bliss et al., ed. D. Orton and R. D. Anderson, Leiden, 1998, p. 154.

50 The Codex of Justinian: A New Annotated Translation, with Parallel Latin and Greek Text, transl. F. H. Blume, I, Cambridge, 2016, pp. c and cxxvi.

51 The Digest is divided into Digestum Vetus (1-24.2), Infortiatum (24.3-38) and Digestum Novum (39-50).

52 De missiven van de VOC-governeur (n. 44 above), p. 30; see The Digest of Justinian, ed. T. Mommsen et al., 4 vols, Philadelphia, 1985, IV, p. 646.
} 
quotes from Seneca's Epistulae morales, XCV.38. In this letter, Seneca lists a series of things that may prevent us from achieving our goals. Nuyts quotes the first part of a sentence: 'Nihil proderit dare praecepta nisi prius amoveris obstantia praeceptis' ('It is to no advantage to give precepts unless you first remove the things that will stand in the way of the precepts'). ${ }^{53}$ Seneca continues the sentence by observing that otherwise it would be like placing weapons by your side and bringing yourself near the foe yet without having your hands free to use those weapons. Nuyts deploys this quotation to rebuke the Governor-General for setting a time limit without ensuring that the winds would allow him to keep to this timetable. His quotation of only part of the sentence could be interpreted as detractio. ${ }^{54}$ Nuyts concludes this passage with the rhetorical question 'Waermet can men mij dan hier accuseeren?' ('So, what can I be accused of here?') He continues that he cannot be blamed, for although he might have predicted that the weather, specifically the northern monsoon, would cause the boats problems, he felt compelled to follow orders.

Later in the letter, Nuyts recalls the diplomatic mission that he had led to the court of the shogun in Edo, Japan shortly after assuming responsibility as Governor of Taiwan. By all accounts the mission was a failure, above all because Nuyts failed to gain an audience with the shogun. ${ }^{55}$ In the letter, however, Nuyts argues that at least the VOC was still able to trade with Japan after the mission. He underlines his point with the quotation 'Bona turpitudo est quae periculum vincat' ('It is a good disgrace which triumphs over danger'). This is one of the apophthegms in the Sententiae of Publilius Syrus (first century BCE). Some of these apophthegms were ascribed at the time to Seneca (the Younger), which explains why Nuyts wrote Seneca's name in the margin. ${ }^{56}$

Nuyts concludes the letter-cum-apologia by citing the Alexandrian poet Claudian (c. 370-404). ${ }^{57}$ In Panegyricus dictus Mallio (Manlio) Theodoro consuli (Carmina, 17, 1l. 227-9), Claudian writes: 'Proximus Diis ille est quem ratio non ira movet, qui facta rependens consilio punire potest' ('He who is closest to the gods is the one whom reason and not anger moves, and who, after weighing up the facts, can mete out punishment advisedly'). Nuyts quotes only the first part ('Proximus ... movet'), another example of detractio. He was clearly hoping that the Governor-General would agree with his line of reasoning rather than following the emotions aroused by Nuyts's apparent ineptness. To be sure, he could simply have made this point in Dutch; but by appealing to antiquity, he presented himself as an intellectual who

\footnotetext{
53 De missiven van de VOC-governeur (n. 44 above), p. 33.

54 Lausberg, Handbook of Literary Rhetoric (n. 49 above), pp. 217-20. Detractio (removing one component) is one of the four categories of change: quadripartita ratio (Quintilian, Institutiones oratoriae, I.v.10 and 38-41). The other three are adjectio (adding one component), transmutatio (changing position) and immutatio (removing one component and adding another).

55 For a detailed account of the diplomatic mission, see Clulow, The Company and the Shogun (n. 37 above), pp. 72-94. Clulow makes the point that although Nuyts was an inept and very 'undiplomatic' diplomat, the mission failed more as a result of VOC strategy rather than Nuyts's personal shortcomings.

${ }^{56}$ De missiven van de VOC-governeur in Taiwan (n. 44 above), p. 91. The transcription gives the marginal note as 'Seneca in prov.' This may refer to Proverbia Senecae, a work falsely attributed to Seneca, or Seneca's De providentia, although I have not found the apophthegm in either work.

57 De missiven van de VOC-governeur in Taiwan (n. 44 above), p. 105.
} 
should be taken seriously and thereby hoped to convince any doubters to accept his arguments.

In conclusion, these examples illustrate that Nuyts was well versed in rhetoric. As one modern scholar has put it, rhetoric, the art of persuading and arguing one's case, was the 'common possession of writers and readers in the sixteenth and seventeenth centuries' ${ }^{58}$ It formed an essential part of the humanist educational programme that developed in grammar schools and universities throughout Europe and was seen as the principal intellectual and linguistic tool for shaping one's identity and developing as an individual. ${ }^{59}$ It is likely that Nuyts's use of rhetoric was informed by standard works such as the Rhetorica ad Herennium and Quintilian's Institutiones oratoriae, which was sometimes treated as an applied manual of rhetoric.

\section{The Use of Classical Texts by Other Dutchmen}

Several of the Dutch missionaries quoted classical authors, although by no means to the same extent as Nuyts. Among these are Johannes Happartius and Robert Junius. ${ }^{60}$ A slightly different example comes from the pen of Georgius Candidius. In the description of the customs of the Siraya people that he wrote in 1628, Candidius expresses surprise at the eloquence of some local leaders. He compares them favourably with the famed Athenian statesman and orator, Demosthenes (fourth century BCE): 'wie niet meyne Demostenem in woorden rycker ende vloijender geweest te hebben' ('and [I] do not think that Demosthenes [himself] was more eloquent and more fluent with words'). ${ }^{61}$ Although there is doubtless an element of hyperbole at work here, Candidius's appeal to Demosthenes serves a serious purpose. It adds color, to use Quintilian's term (Institutiones oratoriae, IV.ii.88), and perhaps even insight into the eloquence of the Siraya people whom Candidius encountered. ${ }^{62}$ It would presumably have challenged expectations about the skills that they possessed. Apart from body tattoos, they had no written culture; but implicit in Candidius's appeal to antiquity is that they were far from being 'savages'. He probably hoped that he could use this argument to justify attempts to convert the Siraya to Christianity, which was his main purpose in engaging with them. There was no doubt a financial aspect to this: Candidius hoped that the VOC would continue to fund missionary activity in Taiwan, and so it was important to give the Governor-General and his

\footnotetext{
58 D. Bush, English Poetry: The Main Currents from Chaucer to the Present, London, 1965, p. 47.

59 S. Greenblatt, Renaissance Self-Fashioning: From More to Shakespeare, Chicago, 1980, p. 162.

${ }^{60}$ In a letter dated 28 October 1645 to an elder in Batavia, Happartius quotes from Ovid's Ars amatoria (II.13) Archief voor de Geschiedenis (n. 25 above), IV, pp. 91-2, and Campbell, Formosa under the Dutch (n. 26 above), pp. 246-7. In a report on his missionary work dated 5 September 1636 Junius included the phrase ta kala duscola ('Beautiful things are difficult') possibly from a Latin work such as Erasmus's Ciceronianus: see Archief voor de Geschiedenis (n. 25 above), III, pp. 85-6, and Campbell, Formosa under the Dutch (n. 26 above), pp. 116-17. Junius used this phrase to explain that while missionary work in Taiwan was difficult, it was nevertheless 'beautiful'.

61 The Formosan Encounter, ed. L. Blussé and N. Everts, 4 vols, Taipei, 1999-2010, I, p. 100.

62 Color has been defined as the 'skilful manipulation of the facts' to make a point. It could be translated as 'gloss' or 'varnish'.
} 
colleagues in Batavia a sense of who the potential converts were. One interesting linguistic feature of Candidius's account is that, although writing in Dutch, he uses a Latin accusative-infinitive construction, with Demosthenes's name in the accusative.

\section{Formosan Exposure to Classical Authors}

So far, the focus of this article has been on the reception of classical authors by Europeans in Taiwan. The question arises as to whether the indigenous Formosans had any exposure to works by these authors. Here, as already noted, we encounter the methodological problem that we have no documents written by Formosans from this period and so must rely on European sources for evidence. Let us therefore analyse the contacts which the Spanish and Dutch had with indigenous Formosans.

One Spanish scholar and missionary who was in Taiwan from 1632 to 1642 was the Dominican Teodoro Quirós de la Madre de Dios. Another was also a Dominican, Jacinto Esquivel del Rosario, who was in Taiwan from 1631 to 1633 . Both men had taught philosophy and theology at the University of Santo Tomás in Manila. ${ }^{63}$ Catholic missionaries in Japan had opened seminaries where Latin was taught to Japanese converts training for the priesthood ${ }^{64}$ but the persecution of Catholics in Japan had brought that to an end. In Taiwan, the Dominicans certainly had a plan to open a seminary where Latin and other subjects such as moral theology would be taught to young Christians from China, Japan, Korea and the Ryukyu Islands in order to train them to become clergy and missionaries in their homelands. ${ }^{65}$ Esquivel, however, was killed on a journey to Japan, possibly to recruit young Japanese for the seminary, and there is unfortunately no firm evidence that these plans materialized. ${ }^{66}$

By contrast, Dutch plans to establish a seminary did succeed. Probably the earliest mention of the seminary comes in an entry in church records for 5 October 1657. This indicates that while the youth of the Siraya were taught in their own language in the morning, in the afternoon they would be taught in Dutch using the Dutch edition of Comenius's primer, Vestibulum, mentioned above. ${ }^{67}$ Thirty pupils were to be chosen; orphans or those from a poor background, but with good memories, fluent in reciting prayers and the catechism, and excelling in reading and writing the Roman alphabet were preferred. ${ }^{68}$ The seminary opened in Soulang near Fort Zeelandia in $1659 .{ }^{69}$ Although a Dutch edition of the Comenius primer was used,

\footnotetext{
63 Borao, The Spanish Experience (n. 11 above), p. 190.

64 Joby, 'Reception of Ancient Authors in Japan' (n. 4 above), p. 273.

65 T. Andrade, How Taiwan Became Chinese: Dutch, Spanish and Han Colonization in the Seventeenth Century, New York, 2009, p. 87.

66 Borao, The Spanish Experience (n. 11 above), p. 182.

67 K. Groeneboer, 'Het Nederlands op Formosa ten tijde van de Verenigde Oost-Indische Compagnie', Ons Erfdeel, 37, 1994, pp. 373-80 (378-9). Unfortunately, a 'Formosan' (I assume Siraya) version of Comenius's primer with dialogues, exercises and a vocabularium has been lost.

${ }^{68}$ Campbell, Formosa under the Dutch (n. 26 above), p. 309.

69 Heylen, 'Dutch Language Policy' (n. 7 above), pp. 232-3.
} 
what is striking about it is the amount of Latin in the book. ${ }^{70}$ It consists for the most part of Dutch words and phrases grouped broadly according to part of speech. Under each Dutch word and phrase is a Latin equivalent. The final part of the book is a rudimentary grammar. Although Dutch is again given priority here, much space is devoted to Latin accidence. There is no record of the extent, if any, to which the indigenous students engaged with the Latin in the book, but they could certainly not avoid seeing it.

As for Greek and Latin authors, the preface to the primer, written by Johannes Seidelius, is in Latin with quotations from ancient authors. One quotation is from Plato in Greek with a Latin translation (Laws, V, 730D2). Seidelius also quotes, with slight modification, from Seneca the Younger (De beneficiis, II.xxv.3). The contents page carries another quotation from Seneca: 'Rerum natura sacra sua non simul tradit. Initiatos nos esse credimus, in VESTIBULO ejus haeremus' ('Nature does not reveal its sacred things all at once. We believe that we are her initiates, but we are lingering in her entryway', Naturales quaestiones, VII.xxx.6), as well as a quotation from Fulgentius (late fifth century-early sixth century): 'Primum ... scientiae VESTIBULUM puto, scire quae nescias' ('I think that the entryway [i.e., first stage] of science [i.e., knowledge] is to know what you do not know', Mythologia, I). ${ }^{71}$ Again, there is no record of whether the indigenous seminarians read these quotations from Latin and Greek authors, but they would doubtless have seen them.

\section{Conclusion}

As with the many other projects initiated by the Dutch in Taiwan, the activities of the seminary were abruptly terminated by Koxinga's invasion in 1662. Nevertheless, in the thirty-eight years of the Dutch presence in Taiwan, books by or referring to classical authors were brought to the island, and several Dutchmen quoted from these authors in their own letters and reports. Many of the examples cited above come from the work of one figure, Pieter Nuyts; however, like Nuyts, other of his compatriots appealed to pagan authors from antiquity in order to make the past 'present', to help themselves and their readers understand that 'present' in the unfamiliar setting of Taiwan, and in some sense to justify their decisions. The appeal by Candidius to Demosthenes was probably motivated by a desire to convince the leaders of the VOC that they should continue to provide financial support for missionary activity in Taiwan.

Little has been said here about the Spanish. There is little evidence of classical books in their communal library at Quelang. Furthermore, in the letters they wrote

\footnotetext{
70 The full title is: Eerste deel der schoolgeleertheyd, genoemt het Portael: Inhoudende de grondtveste der dingen, en onser wijsheyd omtrent de dingen, als mede der Latijnschen tael met de moedertael; Toegeschickt nae de wetten des laetsten spraeck-weeghs, en met veel beelden verlicht; Prima pars scholasticae eruditionis, dicta Vestibulum: continens fundamenta rerum, \& nostrae sapientiae circa res, ut \& Latinae linguae cum vernacula; adornatum juxta leges, novissimae methodi, multisque iconibus illustratum, Amsterdam, 1658.

71 See, e.g., Mythographorum Latinorum tomus alter, complectens Fabii Planciadis Fulgentii: Mythologias, continentiam Virgilianam, \& labellum de prisco sermone, Amsterdam, 1681, Liber I, p. 22: 'Primum itaque ergo [variant reading: ego] scientiae vestibulum puto, Scire quod nescias.'
} 
in Taiwan, they did not appeal very much to pagan antiquity; and there is no evidence that plans to establish a seminary, where both Christian and pagan texts might have been on the syllabus, came to fruition. As for the Formosans, here we face the problem of an absence of sources written by them. The most promising avenue of investigation was the establishment of the Dutch seminary in 1659. Here as elsewhere, however, we cannot hear any Formosan voices responding to the Comenius primer. This reflects a more general problem in reception studies in that we are dependent on European colonizers for information about how predominantly oral cultures received classical texts.

Nevertheless, it has been the aim of this article to provide an initial analysis of the ways in which classical texts were employed in Taiwan, increasing our overall knowledge and understanding of the reception of these works in East Asia. Future publications on the reception of explicitly Christian texts from antiquity will, I hope, add further to our comprehension of how texts written centuries before in quite different cultural settings helped to shape, inform and make sense of early encounters between Europeans and the indigenous people of Taiwan and other groups such as Chinese and Japanese merchants.

Open Access This article is licensed under a Creative Commons Attribution 4.0 International License, which permits use, sharing, adaptation, distribution and reproduction in any medium or format, as long as you give appropriate credit to the original author(s) and the source, provide a link to the Creative Commons licence, and indicate if changes were made. The images or other third party material in this article are included in the article's Creative Commons licence, unless indicated otherwise in a credit line to the material. If material is not included in the article's Creative Commons licence and your intended use is not permitted by statutory regulation or exceeds the permitted use, you will need to obtain permission directly from the copyright holder. To view a copy of this licence, visit http://creativecommons.org/licen ses/by/4.0/.

Publisher's Note Springer Nature remains neutral with regard to jurisdictional claims in published maps and institutional affiliations. 